\title{
HOME GARDENING AMIDST PANDEMIC (HGAP): AN APPROACH IN ADDRESSING STUDENT'S PERSONAL WELFARE
}

\author{
Constancia P. Villar \\ Graduate School, Laguna State Polytechnic University, Santa Cruz, Laguna, Philippines
}

Article DOI: $\underline{\text { https://doi.org/10.36713/epra7419 }}$

DOI No: 10.36713/epra7419

\begin{abstract}
Despite many kinds of research, literature, and journals presenting the benefits of gardening as a strategy to enhance household food security and nutrition, the problem brought by the present scenario especially to the students resulted in the conduct of this study. Using the descriptive method of research, the researcher investigated the relationship of home gardening amidst pandemic as an approach in addressing student's personal welfare as to physical, emotional, and social attributes.

Utilizing a questionnaire were analyzed using Mean, SD, and Pearson correlation coefficient. It was found that student's engagement in home gardening is very high in terms of student's interest, parent's initiative, and teacher's motivation. Moving on to sustainability of home gardening practices in terms of family's support, school's support, and LGU's support, give a very high remarks and was recorded for family's support, and school's support and high remarks for LGU's support. Furthermore, a very high remark was noted for the status of student's personal welfare as to physical, emotional, and social attributes.

The study concluded the established relationship between home gardening engagement and sustainability of home gardening practices in addressing student's personal welfare as to physical, emotional, and social was statistically significant. Thus, the hypothesis which states that there is no significant relationship between home gardening engagement and sustainability of home gardening practices in addressing student's personal welfare as to physical, emotional, and social attributes should be rejected. Based on the findings it is recommended that in order to maintain student engagement in home gardening, parents and teachers should provide continuous motivation by giving rewards and recognition for their effort. Home gardening should be widened and strengthened by the school, community, and family. Local government units (LGU) must support home gardening in their community to help families in their food production especially in this time of the pandemic.
\end{abstract}

KEYWORDS: home gardening, personal welfare, student engagement, sustainability, practices, school, parents, teacher, Local government unit ( $L G U)$

\section{INTRODUCTION}

Almost every country in all corners of the world was greatly alarmed by one type of pandemic that had changed the lives of many individuals. People have been forced to live within the four walls of their homes around the world, a situation they have never been used to. Thinking about their plight and the length of time being in quarantine had a negative impact on a 


\section{SJIF Impact Factor 2021: 8.013| ISI I.F.Value:1.241| Journal DOI: 10.36713/epra2016 ISSN: 2455-7838(Online) EPRA International Journal of Research and Development (IJRD)

person's well-being. The youth in particular, as one being affected greatly by this pandemic, should be given special attention.

The Department of Education (DepEd), through DepEd Order No.12 s.2020 (Adoption of the Basic Education Learning Continuity Plan for School Year 2020-2021 in light of the COVID-19 Public Health Emergency), recognizes as a priority the promotion and protection of the mental health and general welfare of learners in the time of COVID-19 Pandemic.

The Department of Education motivates parents and students to engage in "gulayan sa tahanan" as an extension project of "Gulayan sa Paaralan" one of the beneficial activities during this time. Gardening has always been promoted as a relaxing recreational activity that can provide great personal rewards whether it is an ornamental garden or a food garden.

As explained by Foodtank (2020), Home vegetable gardening can not only increase produce consumption and physical activity-but it is also associated with improved emotional wellbeing. According to a recent study from Princeton University (2020) home gardening had a similar effect on emotional well-being as biking, walking, or dining out. It was the only activity out of the 15 studied for which people with low incomes reported the highest emotional well-being. Similarly, Hillside Atlanta (2019) explains that gardening lowers depression, anxiety, obesity, and heart disease as well as promotes personal happiness, quality of life, and a sense of community.

A study made by Eng et.al (2019) the most significant benefit that can arise from gardening is increased social capital and connections. As children work together to plant and create something meaningful, the result is an improved bond between them. Lehman (2013) emphasizes when it is fun and stress-free, gardening with children can be a connecting relationship. On the other hand, Better Health (2013) stated that by gardening as a family, adults can share their skills and knowledge with children and family members can learn together.

For this reason, the researchers sought to investigate the effect of Home Gardening Amidst Pandemic (HGAP) as an approach in addressing student's personal welfare of Grade 9 and 10 TLE Agricultural Crop students of San Francisco Integrated National High School in Victoria, Laguna.

\section{OBJECTIVES}

The goal of this study was to look into the status of home gardening engagement, sustainability of home gardening practices in addressing student's personal welfare of Grade 9 and 10 TLE agricultural crop students of San Francisco Integrated National High School in Victoria District.

Specifically, the study sought answers to the following questions:

1. What is the status of home gardening engagement in terms of:

1.1 student's interest;

1.2 parent's initiative; and

1.3 teacher's motivation?

2. What is the level of sustainability home gardening practices in terms of:

2.1 family's support;

2.2 school's support; and

2.3 LGU's support?

3. What is the status of student's welfare as to:
3.1 physical;
3.2 emotional; and
3.3 social attributes?

4. Is there a significant relationship between home gardening engagement and sustainability of home gardening practices in addressing student's welfare as to:
4.1 physical;
4.2 emotional; and
4.3 social attributes?

\section{METHODOLOGY}

The respondents of the study were composed of 76 Grade 9 and 10 TLE Agricultural crop production students of San Francisco Integrated National High School in the district of Victoria, Laguna.

A descriptive type of research design through a validated survey questionnaire shall be used in gathering information from the sample respondents.

In answering each specific research question, an appropriate statistical tool shall employ using Mean, Standard deviation, and Pearson correlation coefficient. The mean and standard deviation was used to determine the status of home gardening engagement in terms of student's interest, parent's initiative, and teacher's motivation as well as the level the of sustainable home gardening practices in terms of family's support, school support and LGU's support and the status of student's personal welfare as to physical, emotional and social attributes; Pearson Correlation Coefficient suits the study to find the relationship between home gardening engagement and sustainability of home gardening practices in addressing student's welfare as to physical, emotional and social attributes.

After the survey questionnaire was 


\section{SJIF Impact Factor 2021: 8.013| ISI I.F.Value:1.241| Journal DOI: 10.36713/epra2016 ISSN: 2455-7838(Online) EPRA International Journal of Research and Development (IJRD)

administered, all the information was accumulated, analyzed, investigated, tabulated, and interpreted.

\section{RESULT AND DISCUSSION}

The presentation of the significant findings followed the order as per the assertion of the problem specifically: to determine the status of home gardening engagement in terms of student's interest, parent's initiative, and teacher's motivation; level of sustainability of home gardening practices in terms of family's support, school support and LGU's support; status of student's personal welfare as to physical, emotional and social attributes; and to determine if there is significant relationship between home gardening engagement and sustainability of home gardening practices in addressing student's welfare as to physical, emotional and social attributes.

\section{Status of Home Gardening Engagement}

The first specific research question which this study sought to answer focuses on the status of home gardening amidst pandemic as refer to student's interest, parent's initiative, and teacher's motivation. It was dealt with measurably utilizing mean, standard deviation joined by a 5 point-Likert scale made by the researcher. The table shows the indicative statement, mean, remark and interpretation.

Table 1 presents the status of home gardening in terms of student's interest.

Table 1. Status of Home Gardening Engagement in terms of Student's Interest

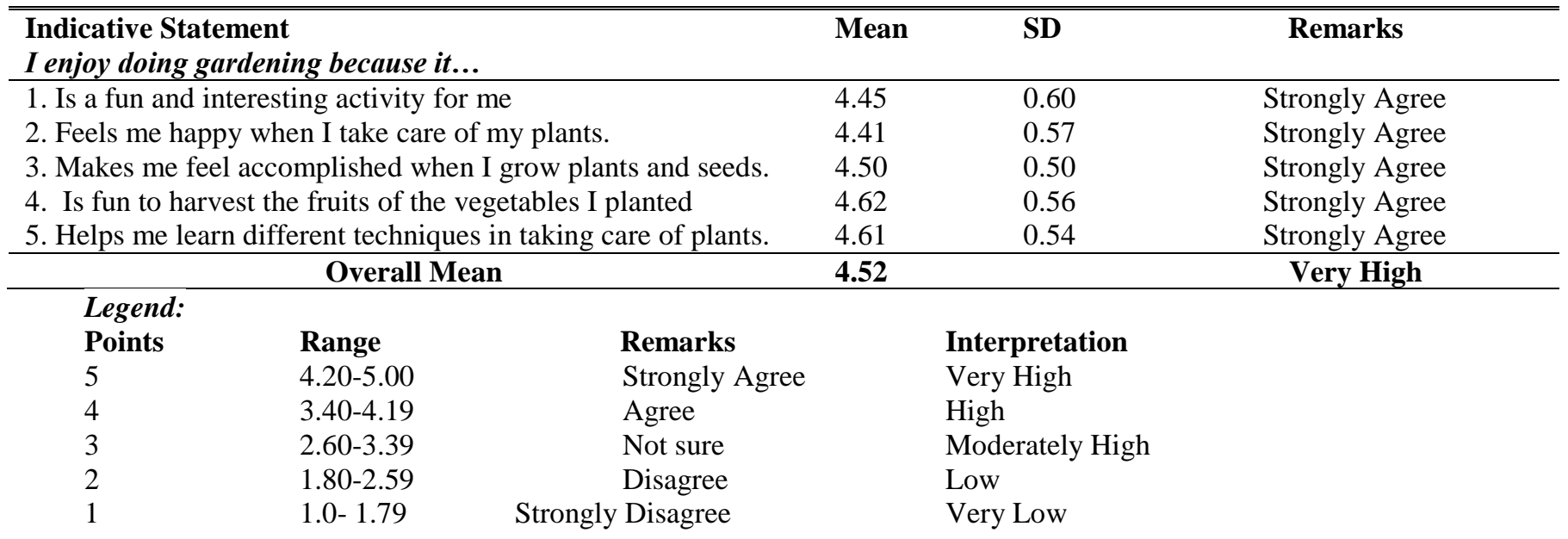

The data in the table present that students strongly agree that home gardening is a fun and interesting activity $(\mathrm{M}=4.45, \mathrm{SD}=0.60)$, makes them happy taking care of plants $(\mathrm{M}=4.41, \mathrm{SD}=0.57)$, makes them feel accomplished growing plants and seeds $(\mathrm{M}=4.50, \mathrm{SD}=0.50)$, makes them feel fun harvesting fruits and vegetables they planted $(\mathrm{M}=4.62, \mathrm{SD}=0.56)$, and helps them learn different techniques in taking care of plants $(\mathrm{M}=4.61, \mathrm{SD}=0.54)$.

The overall mean of 4.52 indicates that students' interest in home gardening is very high.
According to McMane (2013) students who showed interest in participating in gardening activities develop an ability to communicate and work collaboratively. Furthermore, Block et.al, (2012) found that children engaged in a garden and kitchen program were able to self-direct and complete tasks without repeated redirection or close supervision.

Table 2 presents the status of Home Gardening Engagement in terms of parent's initiative. 
Table 2. Status of Home Gardening Engagement in terms of Parent's Initiative

\begin{tabular}{|c|c|c|c|}
\hline $\begin{array}{l}\text { Indicative Statement } \\
\text { My parents/guardians... }\end{array}$ & Mean & SD & Remark \\
\hline $\begin{array}{l}\text { 1. Encourage me to build my little garden. } \\
\text { 2. Join me in planting and taking care of the plants. } \\
\text { 3. Would reward me if I would be able to grow plants. } \\
\text { 4. Praise me for taking good care of plants. } \\
\text { 5. Always check on my garden. }\end{array}$ & $\begin{array}{l}4.41 \\
4.39 \\
4.32 \\
4.43 \\
4.41\end{array}$ & $\begin{array}{l}0.52 \\
0.49 \\
0.70 \\
0.52 \\
0.55\end{array}$ & $\begin{array}{l}\text { Strongly Agree } \\
\text { Strongly Agree } \\
\text { Strongly Agree } \\
\text { Strongly Agree } \\
\text { Strongly Agree }\end{array}$ \\
\hline Overall Mean & 4.39 & & Very High \\
\hline
\end{tabular}

Table 2 recorded a very high level for all statements from the means calculated from the responses of the students. The mean are particularly highest for the two statements, my parents encourage me to build my own little garden $(\mathrm{M}=4.41, \mathrm{SD}=0.52)$, my parents always check on my garden $(\mathrm{M}=4.41$, $\mathrm{SD}=0.55$. The majority of the students seem to be in unison in their responses to this statement, although they have the same computed mean a little bit difference in the result of standard deviation was recorded. On the other hand, the lowest mean was calculated for the statement, My parents would reward me if I would be able to grow plants. This statement also recorded a relatively high standard deviation of 0.70 which is the highest among the statements. This means that compared to the other four, this statement garnered more varied responses from the students. Though all interpreted as very high level, the values are more spread out compared to the other four statements with lower standard deviations.

The overall mean of 4.39 indicates that the status of home gardening engagement in terms of parent's initiative is very high. In accordance with Dansal and Aguanta (2014), the effectiveness of vegetable gardening is significantly linked to the interest of the student in the program, parental support, and the extent of hands-on learning through the direct and meaningful learning experience with cooperation from home or parental support.

Table 3. Status of Home Gardening Engagement in terms of Teacher's Motivation

\begin{tabular}{|c|c|c|c|}
\hline $\begin{array}{l}\text { Indicative Statement } \\
\text { My teacher... }\end{array}$ & Mean & SD & Remark \\
\hline $\begin{array}{l}\text { 1. Encourages me to build my little garden. } \\
\text { 2. Share his/her knowledge in taking care of plants. } \\
\text { 3. Would reward me if I would be able to grow plants. } \\
\text { 4. Praises me for taking good care of plants. } \\
\text { 5. Always checks on my garden. }\end{array}$ & $\begin{array}{l}4.34 \\
4.37 \\
4.26 \\
4.37 \\
4.20\end{array}$ & $\begin{array}{l}0.48 \\
0.49 \\
0.53 \\
0.51 \\
0.71\end{array}$ & $\begin{array}{l}\text { Strongly Agree } \\
\text { Strongly Agree } \\
\text { Strongly Agree } \\
\text { Strongly Agree } \\
\text { Strongly Agree }\end{array}$ \\
\hline Overall Mean & 4.31 & & Very High \\
\hline $\begin{array}{l}\text { As shown in table } 4 \text { students indicated a very } \\
\text { high level of home gardening engagement in terms of } \\
\text { teacher's motivation with an overall mean of } 4.31 \text {. } \\
\text { Based on the presented data the statement in number } 2 \\
\text { which is my teacher shares his/her knowledge in taking } \\
\text { care of plants with a mean of }(\mathrm{M}=4.37, \mathrm{SD}=0.49) \text { has } \\
\text { the same computed mean in statement number } 4 \text { my } \\
\text { teacher praises me for taking good care of plants } \\
(\mathrm{M}=4.37, \mathrm{SD}=0.51) \text {. Both of the statement has the same } \\
\text { mean with a small difference in standard deviation was } \\
\text { also recorded. On the other hand statement for the } \\
\text { teacher would reward me if I would be able to grow }\end{array}$ & \multicolumn{3}{|c|}{$\begin{array}{l}\text { plants with a mean of }(\mathrm{M}=4.26, \mathrm{SD}=0.53) \text { to continue } \\
\text { an }(\mathrm{M}=4.20, \mathrm{SD}=0.71) \text { for statement my teacher always } \\
\text { checks on my garden, the standard deviation here is a } \\
\text { bit higher than other statements that show very short } \\
\text { distances in students responses. According to Filgona } \\
\text { (2020), highly motivated learners are likely to learn } \\
\text { easily and make any activities fun doing, while } \\
\text { unmotivated learners can probably learn very little and } \\
\text { make tasks painful and frustrating in general. Similarly, } \\
\text { DiClaudio, Hughes, and Savoca (2013) claim the } \\
\text { important role of a teacher in motivating students to } \\
\text { engage in worthwhile activities like gardening. }\end{array}$} \\
\hline
\end{tabular}


Teachers believe that implementing new learning styles and motivation can help students to engage more.

\section{Sustainability of Home Gardening Practices}

The second research question which this study sought to answer focuses on the sustainability of home gardening practices in terms of family support, school support, and LGU's support.

Table 4. Level of Sustainability of Home Gardening Practices in terms of
Table 4 presents the sustainability of home gardening practices in terms of family support.

This section answers the second specific research question which focuses on the sustainability of home gardening practices in terms of family support.

\section{Indicative Statement}

Mean

Family's Support

My family...

1. Is involved in the garden plans from the very beginning.

2. Joins me in planting and taking care of the plants.

3. Helps me build a children/students-theme garden.

4. Let me harvest home-grown produce.

5. Share their knowledge and skills in gardening.

$\begin{array}{ll}4.28 & 0.60 \\ 4.32 & 0.55 \\ 4.29 & 0.58 \\ 4.32 & 0.52 \\ 4.53 & 0.53\end{array}$

\subsection{8}

SD

0.55

0.58

0.53
Strongly Agree

Strongly Agree

Strongly Agree

Strongly Agree

Strongly Agree

\section{Overall Mean}

The result also presented the highest $(\mathrm{M}=4.53$ $\mathrm{SD}=0.53$ ) with remarks of strongly agree and verbal interpretation of very high for the statements my family share their knowledge and skills in gardening. Data reveals a lowest $(\mathrm{M}=4.28, \mathrm{SD}=0.60)$ for the statement my family is involved in the garden plans from the very beginning. A similar mean of 4.32 is also recorded in the number two and four statements with a little bit

different in standard deviation.

Very High

According to Camey et. Al., (2013) Family and social relationships can also be strengthened through community gardening. As mentioned by Borbon (2019) another benefit of having a family garden is that it improves family well-being. As a result, the family bond is strengthened and further developed.

Table 5. Level of Sustainability of Home Gardening Practices in terms of School's Support

\begin{tabular}{|c|c|c|c|}
\hline $\begin{array}{l}\text { Indicative Statement } \\
\text { Our school... }\end{array}$ & Mean & SD & Remark \\
\hline $\begin{array}{l}\text { 1. Has a clear policy on home gardening. } \\
\text { 2. Helps provide seedlings and other gardening needs. } \\
\text { 3. Has a merit system for home gardening. } \\
\text { 4. Features our home garden on its publications. } \\
\text { 5. (Its teachers) Visit us to check on our gardens. }\end{array}$ & $\begin{array}{l}4.42 \\
4.25 \\
4.31 \\
4.34 \\
4.25\end{array}$ & $\begin{array}{l}0.55 \\
0.57 \\
0.64 \\
0.66 \\
0.68\end{array}$ & $\begin{array}{l}\text { Strongly Agree } \\
\text { Strongly Agree } \\
\text { Strongly Agree } \\
\text { Strongly Agree } \\
\text { Strongly Agree }\end{array}$ \\
\hline Overall Mean & \multicolumn{3}{|c|}{ Very High } \\
\hline $\begin{array}{l}\text { Table } 5 \text { shows the mean level of sustainability } \\
\text { of home gardening practices in terms of school's } \\
\text { support, in the statement, our school has a clear policy } \\
\text { on home gardening with an }(\mathrm{M}=4.42, \mathrm{SD}=0.55) \text { with } \\
\text { remarks of strongly agree and verbal interpretation of } \\
\text { Very High. It also shows the highest mean level. } \\
\text { On the other hand, students remark strongly } \\
\text { agree with the statements about our school helps } \\
\text { provide seedlings and other gardening needs with an } \\
\text { (M=4.25, } \mathrm{SD}=0.57) \text {, has a merit system for home } \\
\text { gardening }(\mathrm{M}=4.31, \mathrm{SD}=0.64) \text {, features our home } \\
\text { arden in }\end{array}$ & \multicolumn{3}{|c|}{$\begin{array}{l}\text { teachers visit us to check on our gardens }(\mathrm{M}=4.25 \text {, } \\
\mathrm{SD}=0.68) \text {. Furthermore, the data in the table also shows } \\
\text { the total mean level of sustainability of home gardening } \\
\text { practices in terms of school support with a total } \\
(\mathrm{M}=4.31, \mathrm{SD}=) \text { interpreted as Very High. The need for } \\
\text { school's support in the sustainability of home gardening } \\
\text { practices is important as mentioned by Mc Cully (2012) } \\
\text { provision of practical, up-to-date, basic information on } \\
\text { home gardening for vocational agriculture students } \\
\text { with limited knowledge of vegetable gardening is } \\
\text { important. }\end{array}$} \\
\hline
\end{tabular}
garden in its publications $(\mathrm{M}=4.34, \mathrm{SD}=0.66)$ and its 


\section{SJIF Impact Factor 2021: 8.013| ISI I.F.Value:1.241| Journal DOI: 10.36713/epra2016 ISSN: 2455-7838(Online) EPRA International Journal of Research and Development (IJRD) Volume: 6 | Issue: 7 | July 2021 - Peer Reviewed Journal}

Table 6. Level of Sustainability of Home Gardening Practices in terms of LGU's Support

\begin{tabular}{|c|c|c|c|}
\hline $\begin{array}{l}\text { Indicative Statement } \\
\text { Our barangay... }\end{array}$ & Mean & SD & Remark \\
\hline $\begin{array}{l}\text { 1. Has a clear policy on home gardening. } \\
\text { 2. Helps provide seedlings and other gardening needs. } \\
\text { 3. Has a merit system for home gardening. } \\
\text { 4. Promote home gardening in our community. } \\
\text { 5. (its officials) Visits us to check on our gardens. }\end{array}$ & $\begin{array}{l}4.04 \\
4.08 \\
4.04 \\
4.12 \\
3.75\end{array}$ & $\begin{array}{l}0.72 \\
0.63 \\
0.70 \\
0.65 \\
0.83\end{array}$ & $\begin{array}{l}\text { Agree } \\
\text { Agree } \\
\text { Agree } \\
\text { Agree } \\
\text { Agree }\end{array}$ \\
\hline Overall Mean & 4.01 & & High \\
\hline $\begin{array}{l}\text { Presented in table } 6 \text { is the result of the level of } \\
\text { sustainability of home gardening in terms of LGU's } \\
\text { support with a total of ( } \mathrm{M}=4.01, \mathrm{SD}=) \text { with a verbal } \\
\text { interpretation of High. Also observed in the table the } \\
\text { highest mean level }(\mathrm{M}=4.12, \mathrm{SD}=0.65) \text { with remarks of } \\
\text { agree and verbal interpretation of Very high for } \\
\text { statement our barangay promote home gardening in our } \\
\text { community. } \\
\text { The lowest mean, on the other hand, has been } \\
\text { calculated for the statement our barangay officials visit } \\
\text { us to check our gardens (M=3.75). This statement, } \\
\text { however, recorded the most varied responses with } \\
\text { SD=0.83. Data indicates the same mean of M=4.04 for } \\
\text { the statement our barangay has a clear policy on home } \\
\text { gardening and our barangay has a merit system for } \\
\text { home gardening and a minimal difference in standard } \\
\text { deviation. The recognition of the respondents in the } \\
\text { importance of LGU's support in the sustainability of } \\
\text { home gardening practices is evident. As mentioned by } \\
\text { Mc Intosh (2011) the local government plays important }\end{array}$ & \multicolumn{3}{|c|}{$\begin{array}{l}\text { Results show that students strongly agree that } \\
\text { doing home gardening helps them gain strength } \\
\text { through regular exposure to fresh air and sunlight } \\
(\mathrm{M}=4.58 \text {, SD=0.50) helps them exercise their entire } \\
\text { body through walking, reaching, bending, and digging } \\
(\mathrm{M}=4.61, \mathrm{SD}=0.49) \text {, helps them feel more active and } \\
\text { alive }(\mathrm{M}=4.63, \mathrm{SD}=0.49) \text {, helps them improve their } \\
\text { endurance, strength, mobility, and flexibility }(\mathrm{M}=4.47 \text {, } \\
\mathrm{SD}=0.50) \text { and makes them physically fit through } \\
\text { regular eating of fresh vegetables }(\mathrm{M}=4.51, \mathrm{SD}=0.50) \text {. }\end{array}$} \\
\hline
\end{tabular}

Table 7. Status of Student's Personal Welfare as to Physical Attributes

\begin{tabular}{|c|c|c|c|}
\hline $\begin{array}{l}\text { Indicative Statement } \\
\text { Doing gardening... }\end{array}$ & Mean & SD & Remark \\
\hline $\begin{array}{l}\text { 1. Help me gain strength through regular exposure to fresh air } \\
\text { and sunlight. }\end{array}$ & 4.58 & 0.50 & Strongly Agree \\
\hline $\begin{array}{l}\text { 2. Exercise my entire body through walking, reaching, bending, } \\
\text { and digging. }\end{array}$ & 4.61 & 0.49 & Strongly Agree \\
\hline 3. Feels me more active and alive. & 4.63 & 0.49 & Strongly Agree \\
\hline 4. Improves my endurance, strength, mobility, and flexibility. & 4.47 & 0.50 & Strongly Agree \\
\hline $\begin{array}{l}\text { 5. Makes me physically fit through regular eating of fresh } \\
\text { vegetables. }\end{array}$ & 4.51 & 0.50 & Strongly Agree \\
\hline Overall Mean & 4.56 & & Very High \\
\hline
\end{tabular}


Data shows that the standard deviation implies closely similar responses obtained from the students. The overall mean of 4.56 indicates that the status of student's personal welfare as physical attributes is very high.

According to Ohly et.al, (2016) gardening programs are increasingly popular, with suggested benefits including healthier eating and increased physical activity. Similarly, Eng et.al, (2019) Gardening is quite beneficial to children's physical, cognitive, and motor development. Moving tools, digging in the soil, and feeling the dirt in their palms are all experiences that add to the physical development of children.

Table 8. Status of Student's Personal Welfare as to Emotional Attributes

\begin{tabular}{|c|c|c|c|}
\hline $\begin{array}{l}\text { Indicative Statement } \\
\text { Doing gardening... }\end{array}$ & Mean & SD & Remark \\
\hline 1. Helps me relieve my stress from stressful activities. & 4.59 & 0.52 & Strongly Agree \\
\hline 2. Makes me feel satisfied and happy. & 4.61 & 0.49 & Strongly Agree \\
\hline 3. Releases my boredom and negative vibes. & 4.59 & 0.49 & Strongly Agree \\
\hline 4. Feels more relax and calm. & 4.53 & 0.53 & Strongly Agree \\
\hline $\begin{array}{l}\text { 5. Helps me become less sensitive and irritable and teaches me } \\
\text { to become patient. }\end{array}$ & 4.62 & 0.49 & Strongly Agree \\
\hline Overall Mean & 4.59 & & Very High \\
\hline
\end{tabular}

As shown in table 8 students strongly agree that doing home gardening helps them relieve stress from stressful activities $(\mathrm{M}=4.59, \mathrm{SD}=0.52)$, makes them feel satisfied and happy ( $M=4.61, S D=0.49)$, releases their boredom and negative vibes $(\mathrm{M}=4.59$, $\mathrm{SD}=0.49)$, feels them more relax and calm $(\mathrm{M}=4.53$, $\mathrm{SD}=0.53$ ) and helps them become less sensitive, irritable and teaches them to become patient $(\mathrm{M}=4.62$, $\mathrm{SD}=0.49$ ).

It can be further observed close and similar results on mean and standard deviation which signify relatively close responses from the students. The overall mean of 4.59 indicates that the status of student's personal welfare as to emotional attributes is very high. As shown in the study conducted by Lier, Utter, and Denny (2016) students involved in gardening report slightly lower levels of depressive symptoms and improved emotional well-being and are more connected to their families than students who are not involved in gardening. Similary Dorcheus (2016) stated in his research study found that both at the beginning and end of youth gardening experiences, participants reported feeling more positive than negative emotions.

Table 9 presents the status of student's personal welfare as to social attributes.

Table 9. Status of Student's Personal Welfare as to Social attributes

\begin{tabular}{|c|c|c|c|}
\hline $\begin{array}{l}\text { Indicative Statement } \\
\text { Doing gardening... }\end{array}$ & Mean & SD & Remark \\
\hline 1. Brings enjoyment to me and my family. & 4.74 & 0.47 & Strongly Agree \\
\hline 2. Gives me a sense of belonging. & 4.75 & 0.44 & Strongly Agree \\
\hline 3. Serves as a bonding time with my family. & 4.67 & 0.50 & Strongly Agree \\
\hline 4. Promotes closeness to my family. & 4.59 & 0.55 & Strongly Agree \\
\hline 5. Teaches me to be responsible and cooperative. & 4.66 & 0.50 & Strongly Agree \\
\hline Overall Mean & 4.68 & & Very High \\
\hline
\end{tabular}

Similar to the student's responses presented in Tables 7 and 8, Table 9 recorded a very high level for all statements from the means calculated from the responses of the students. As observed in the table student's strongly agree that doing home gardening brings enjoyment to them and their family $(M=4.74$, $\mathrm{SD}=0.47)$, gives them a sense of belonging $(\mathrm{M}=4.75$, $\mathrm{SD}=0.44)$, serves as a bonding time for their family $(\mathrm{M}=4.67, \mathrm{SD}=0.50)$, promotes closeness to their family

(c) 2021 EPRA IJRD | Journal DOI: https://doi.org/10.36713/epra2016 | www.eprajournals.com |180 | 
$(\mathrm{M}=4.59, \mathrm{SD}=0.55)$, and teaches them to be responsible and cooperative. $(\mathrm{M}=4.66, \mathrm{SD}=0.50)$.

Data reveals closely similar responses obtained from the students as shown in the result of standard deviation. The overall mean of 4.68 indicates that the status of student's personal welfare as to social attributes is very high. Mcfarland and Waliczek (2018) highlighted the importance of interactions in the garden with families. According to them home gardening can be used as a location for social interactions sharing of experiences and bounty with others as well as developing stories and memories. Eng et.al, (2019). The most significant benefit that can arise from gardening is increased social capital and connections. As children work together to plant and create something meaningful, the result is an improved bond between them.

Relationship of Home Gardening Engagement and Sustainability of Home Gardening Practices in Addressing Student's Personal welfare.

This section aims to address the fourth research question which concerns the relationship of home gardening engagement and sustainability of home gardening practices in addressing student's personal welfare.

Table 11 presents the significant relationship of home gardening engagement and sustainability of home gardening practices in addressing student's personal welfare as to physical attributes.

Results show that home gardening engagement as to student's interest $(\mathrm{r}=0.482, p=0.000)$, parent's initiative $(\mathrm{r}=0.415, p=0.000)$, and teacher's motivation $(\mathrm{r}=0.473, p=0.000)$ were found moderately related to student's welfare in terms of physical attributes. With regards to home gardening sustainability, there is a moderate relationship between LGU's support $(\mathrm{r}=0.516, p=0.000)$, school's support ( $\mathrm{r}=0.472, p=0.000)$, and student's personal welfare as to physical attributes. Family's support $(\mathrm{r}=0.393, p=0.000)$ however, shows a weak relationship with student's personal welfare as to physical attributes.

Furthermore, it shows that the established relationship was statistically significant at a 0.01 level of significance. Thus, the hypothesis that states that there is no significant relationship of home gardening engagement and sustainability of home gardening practices in addressing student's personal welfare as to physical attributes should be rejected.

Table 10. Relationship of Home gardening Engagement and Sustainability of Home Gardening Practices in Addressing Student's Personal welfare as to Physical Attributes

\begin{tabular}{cllll}
\hline \hline Predictive Indicator & $\mathbf{r}$ & Interpretation & $\boldsymbol{p}$ & Analysis \\
\hline Home Gardening Engagement & & & & \\
- Student's Interest & $0.482^{* *}$ & Moderate & 0.000 & Significant \\
- Parent's Initiative & $0.415^{* *}$ & Moderate & 0.000 & Significant \\
• Teacher's Motivation & $0.473^{* *}$ & Moderate & 0.000 & Significant \\
Home Gardening Sustainability & & & & \\
- Family's Support & $0.393^{* *}$ & Weak & 0.000 & Significant \\
- School's Support & $0.472^{* *}$ & Moderate & 0.000 & Significant \\
- LGU's Support & $0.516^{* *}$ & Moderate & 0.000 & Significant
\end{tabular}

** Significant at 0.01 level ( 2 - tailed test)

*Significant at 0.05 level (2-tailed test)

According to Schmutz et., al. (2014) regular involvement in gardening increases overall levels of physical activity and fitness burn more calories and hence contribute to healthy weight management and reducing the risk of obesity. This is somehow related to the findings of Wallace (2020 plants, both indoor and outdoor, are natural air purifiers, taking air pollution and carbon dioxide in and releasing oxygen in return. This can aid in improving overall health and well-being while reducing exposure to harsh and dangerous toxins. Similarly, Thompson (2018) explains that working in the garden restores dexterity and strength, and the aerobic exercise that is involved can easily use the same number of calories as might be expended in a gym.

Table 11 presents the significant relationship of home gardening engagement and sustainability of home gardening practices in addressing student's personal welfare as to emotional attributes. 
Table 11. Relationship of Home Gardening Engagement and Sustainability of Home Gardening Practices in Addressing Student's Personal welfare as to Emotional Attributes

\begin{tabular}{ccccc}
\hline \hline Predictive Indicator & r & Interpretation & $\boldsymbol{p}$ & Analysis \\
\hline Home Gardening Engagement & & & & \\
$\bullet \quad$ Student's Interest & $0.370^{* *}$ & Weak & 0.001 & Significant \\
- Parent's Initiative & $0.331^{* *}$ & Weak & 0.004 & Significant \\
- Teacher's Motivation & $0.376^{* *}$ & Weak & 0.001 & Significant \\
Home Gardening Sustainability & & & \\
$\bullet \quad$ Family's Support & & & \\
$\bullet \quad$ School's Support & $0.376^{* *}$ & Weak & 0.001 & Significant \\
$\bullet \quad$ LGU's Support & $0.268^{*}$ & Weak & 0.020 & Significant \\
& $0.397^{* *}$ & Weak & 0.000 & Significant
\end{tabular}

Results show that home gardening engagement as to student's interest $(\mathrm{r}=0.370, p=0.001)$, parent's initiative $(\mathrm{r}=0.331, p=0.004)$, and teacher's motivation ( $\mathrm{r}=0.376, p=0.001)$ were found weak (relationship) with student's welfare in terms of emotional attributes. With regard to home gardening sustainability, there is a weak relationship between family's support $(\mathrm{r}=0.376, p=0.001)$, school's support $(\mathrm{r}=0.268, p=0.020)$, LGU's support $(\mathrm{r}=0516, p=0.000)$, and student's personal welfare as to emotional.

Further, it shows that the established relationship was statistically significant at a 0.01 level of significance. Thus, the hypothesis that states that there is no significant relationship of home gardening engagement and sustainability of home gardening practices in addressing student's personal welfare as to emotional welfare should be rejected.

These findings are the same as Sunga and Advincula (2021) in this time of pandemic engagement in gardening brings psychological experience and interest that result in stress relief and improved mood. Eng et.al., (2019) claims that gardening also increases creativity and inspiration; positively improves participants' mental well-being.

Table 12 presents the significant relationship of home gardening engagement and sustainability of home gardening practices in addressing student's personal welfare as to social attributes.

Table 12. Relationship of Home Gardening Engagement and Sustainability of Home Gardening Practices in Addressing Student's Personal welfare as to Social Attributes

\begin{tabular}{cllll}
\hline \hline Predictive Indicator & r & Interpretation & $\boldsymbol{p}$ & Analysis \\
\hline Home Gardening Engagement & & & & \\
- Student's Interest & $0.484^{* *}$ & Moderate & 0.000 & Significant \\
- Parent's Initiative & $0.451^{* *}$ & Moderate & 0.000 & Significant \\
- Teacher's Motivation & $0.375^{* *}$ & Weak & 0.001 & Significant
\end{tabular}

Home Gardening Sustainability

- Family's Support

- School's Support

- LGU's Support

$$
\begin{aligned}
& 0.412 * * \\
& 0.368 * * \\
& 0.401 * *
\end{aligned}
$$

Moderate

Weak

Moderate
0.000

0.001

0.000
Significant

Significant

Significant
Results show that home gardening engagement as to student's interest $(r=0.484, p=0.000)$, and parent's initiative $(\mathrm{r}=0.451, p=0.000)$ were found moderately related to student's welfare in terms of 


\section{SJIF Impact Factor 2021: 8.013| ISI I.F.Value:1.241| Journal DOI: 10.36713/epra2016 ISSN: 2455-7838(Online) EPRA International Journal of Research and Development (IJRD)

social attributes. On the other hand teacher's motivation $(\mathrm{r}=0.375, p=0.001)$ shows a weak relationship to student's welfare in terms of social attribute. With regard to home gardening sustainability, there is a moderate relationship between family support $(\mathrm{r}=0.412$, $p=0.000)$, LGU's support $(\mathrm{r}=0.401, p=0.000)$, and student's personal welfare as to social attributes. School's support ( $\mathrm{r}=0.368, p=0.001)$ however, shows a weak relationship to student's personal welfare as to social attributes.

Further, it shows that the established relationship was statistically significant at 0.01 level of significance. Thus, the hypothesis that states that there is no significant relationship of home gardening engagement and sustainability of home gardening practices in addressing student's personal welfare as to social should be rejected.

The results of the current support the claim of Enroth (2019) that gardening can transcend social problems. No matter what a person's race or social status may be, a love for plants can bring people together. Several researchers and projects have shown gardening to promote positive social interaction.

\section{CONCLUSION}

After thorough analyses of the gathered and treated data, the researcher arrived at the following conclusions.

Results shows that home gardening engagement and sustainability of home gardening practices in addressing student's personal welfare as to physical, emotional, and social attributes was statistically significant at 0.01 level of significance therefore the hypothesis that there is no significant relationship of home gardening engagement and sustainability of home gardening practices in addressing student's personal welfare as to physical, emotional and social attributes should be rejected.

\section{RECOMMENDATION}

Considering the findings and conclusions of this investigation, the researcher made the following recommendations.

1. In order to maintain student engagement in home gardening parents and teachers should provide continuous motivation by giving rewards and recognition for their effort.

2. Since home gardening amidst pandemic has a positive effect on student's personal welfare, the researcher suggests that it should be widened and strengthened by a school, community, and family.

3. Local Government Unit must support home gardening in their community to help families with their food production especially during this time of the pandemic.

4. It is further recommended that the Department of Education to conduct teacher's training for home gardening to help the students in providing important information regarding home gardening.

5. It is recommended for future researchers to check and improve the reliability of the research instrument for a larger sample size.

6. More research and empirical data are also needed to evaluate the role of home gardens in a crisis like pandemic and post-crisis situations, as well as their economic value and impacts on food security, nutrition, and family's well-being.

\section{REFERENCES}

1. Better Health (2013) Gardens for all- a health activities. Retrieved on 16th of November 2020 from

https://www.betterhealth.vic.gov.au/health/healthyli ving/gardens-for-all-a-health-activity

2. Block, K., Gibbs, L., Staiger, P., Gold, L., Johnson, B., Macfarlane, S., Townsend, M. (2012). Growing community: The impact of the Stephanie Alexander Kitchen Garden Program on the social and learning environment in primary schools. Retrieved on $21^{\text {st }}$ of April 2021 from https://pubmed.ncbi.nlm.nih.gov/22167317/.

3. Eng, S., Khun, T., Jower, S., and Murro, M. (2019) Healthy Lifestyle Through Gardening: The Art of Sharing. Retrieved on 23rd of November 2020 from https://www.researchgate.net/publication/33242611 2_Healthy_Lifestyle_Through_Home_Gardening_T he_Art_of_Sharing

4. Dansal, J. and Aguanta L. (2014)Effectiveness Of Gulayan Sa Paaralan Program In Tambo Elementary School, Lanao Del Norte, Philippines https://www.thesisabstracts.com/Thesis Abstract_847_Effectiveness-Of-Gulayan-SaPaaralan-Program-In-Tambo-Elementary-SchoolLanao-Del-Norte-Philippines.html

5. DepEd (2020) DepEd Order No. 12 s. 2020 Adoption of the Basic Education Learning Continuity Plan for School Year 2020-2021 in light of COVID-19 Public Health Emergency. Retrieved on $15^{\text {th }}$ of November 2020 from https://www.deped.gov.ph/2020/06/19/june-192020-do-012-2020-adoption-of-the-basiceducation-learning-continuity-plan-for-schoolyear-2020-2021-in-the-light-of-the-covid-19public-health-emergency/

6. DepEd (2018) DepEd Memorandum No. 095, s. 2018 Implementation of Gulayan sa Paaralan Program (GPP). Retrieved on $15^{\text {th }}$ of November 2020 from https://www.deped.gov.ph/2018/05/29/may-29- 


\section{SJIF Impact Factor 2021: 8.013| ISI I.F.Value:1.241| Journal DOI: 10.36713/epra2016 ISSN: 2455-7838(Online) EPRA International Journal of Research and Development (IJRD)

2018-dm-095-s-2018-sustaining-the-

implementation-of-the-gulayan-sa-paaralanprogram-in-public-elementary-and-secondaryschools-nationwidel

7. DiClaudio, D., Hughes, J., and Savoca, L. (2013). Learning through the Garden. Retrieved on 1st of December $2020 \quad$ from https://njaes.rutgers.edu/fs1211/

8. Dorcheus, M. (2016) Impact of Youth Gardening on Emotional Wellbeing. Retrieved on 21st of April 2021

from https://wasatchgardens.org/images/docspdfs/Dorcheus_Final.pdf

9. Enroth, C. (2019). Is Gardening Still Important to Humans? Yes, because gardens can heal! Retrieved on $26^{\text {th }} \quad$ April 2021 from https://extension.illinois.edu/blogs/goodgrowing/2019-06-05-gardening-still-importanthumans-yes-because-gardens-can-heal.

10. Filgona J., Sakiyo J., Gwany D., Okoronka A. (2020) Motivation in Learning. Retrieved on 16th of November $2020 \quad$ from https://www.researchgate.net/publication/34419998 3_Motivation_in_Learning

11. Foodtank (2020) Home Gardening Promotes Mental Health During COVID-19 Pandemic 2020. Retrieved on 11th October 2020, from https://foodtank.com/news/2020/08/homegardening-promotes-mental-health-during-covid19/

12. Hillside (2019) Horticulture Therapy, Mental Health. How Plants Improve Your Mental Physical Health. Retrieved on 11th October 2020, from https://hside.org/plants-improve-mentalphysical-health/

13. Lehman, B. (2013). Parents and children gardening together: A relationship connector - Part 2. Retrieved on 1st of December 2020 from https://www.canr.msu.edu/news/parents_and_child ren_gardening_together_a_relationship_connector _part_2

14. Lier, E., Utter, j., Denny, s., and Lucassen, M. (2016) Home Gardening and the Health and WellBeing of Adolescents. Retrieved on $11^{\text {th }}$ of April 2021 from https://www.researchgate.net/publication/30933971 7_Home_Gardening_and_the_Health_and_WellBeing_of_Adolescents

15. Mc Cully, J. (2012) A reference Unit on Home Vegetable Gardening.Retrieved on 20th of April 2021

from

https://eric.ed.gov/?q=thesis + on + Home + gardenin g\&id $=$ ED 133437
16. Mcfarland, A. and Waliczek T.M. (2018) Understanding Motivations for Gardening Using a Qualitative General Inductive Approach. Retrieved on 21st of April 2021 from https://www.researchgate.net/publication/32604936 8_Understanding_Motivations_for_Gardening_Usi ng_a_Qualitative_General_Inductive_Approach

17. Mc Intosh, P. (2011) Gardening A Growing Activity. Retrieved on 20th of April 2021 from https://files.eric.ed.gov/fulltext/EJ962387.pdf

18. McMane, E. (2013) Growing empathy: an explore owing empathy: an exploratory study on the effects of school acts of school gardens on children dens on children's social and emotional development: a project-based upon an investigation at Berkeley Independent Study, Berkeley, California. Retrieved on 21st of April 2021 from https://scholarworks.smith.edu/cgi/viewcontent.cgi? article $=1704 \&$ context $=$ theses

19. Ohly, H., Gentry, S., Wigglesworth, R., Bethel A., Lovell, R., Garside, R., A systematic review of the health and well-being impacts of school gardening: synthesis of quantitative and qualitative evidence. https://bmcpublichealth.biomedcentral.com/articles /10.1186/s12889-016-2941-0?optIn=false Retrieved on 21st of April 2021.

20. Princeton University, (2020) Emotional well-being while home gardening similar to other popular activities. Retrieved on 21st of April 2021, from https://www.sciencedaily.com/releases/2020/05/200 511142141.htm

21. Schmutz, U., Lennartsson, M., Williams, S. Devereaux, M. and Davies, G. (2014). The benefits of gardening and food growing for health and wellbeing. Retrieved on 21st of April 2021 from https://www.researchgate.net/publication/26311731 8_The_benefits_of_gardening_and_food_growing_f or_health_and_wellbeing

22. Sunga A. and Advincula J. (2021) The "plantito/plantita" home gardening during the pandemic. Retrieved on 23rd of April 2021 from http://siba-

ese.unisalento.it/index.php/cpgp/article/view/22898

23. Thompson, R. (2018) Gardening for health: a regular dose of gardening. Retrieved on 20th of November $2020 \quad$ from https://www.ncbi.nlm.nih.gov/pmc/articles/PMC633 4070

24. Wallace, P. (2020) The Importance of Gardening During the COVID-19 Pandemic. Retrieved on $20^{\text {th }}$ of January $2020 \quad$ from https://www.psychreg.org/gardening-covid-19/ 